\title{
POROVNÁNÍ METOD VÝPOČTU POTENCIÁLNÍ EVAPOTRANSPIRACE
}

\section{A COMPARISON OF METHODS FOR EVALUATION OF POTENTIAL EVAPOTRANSPIRATION}

\author{
Martin Bednáŕ ${ }^{*}, 1$, Daniel Marton ${ }^{1}$
}

*bednar.m@fce.vutbr.cz

${ }^{1}$ Vysoké učení technické v Brně, Fakulta stavební, Ústav vodního hospodářství krajiny, Žižkova 17, 60200 Brno

\begin{abstract}
Abstrakt
Př́spěvek představí využití několika různých metod pro stanovení potenciální evapotranspirace a jejich vliv na stanovení odtoku vody z povodí v podmínkách klimatické změny. Jedná se o metody založené na průměrných teplotách a př́ípadně extraterestrické radiaci. Konkrétně se jedná o metody Blaney-Criddle, Hargreaves, Turc a Thornthwaite. Metody byly testovány pomocí bilančního srážko-odtokového modelu kalibrovaného na části povodí řeky Dyje. Výsledky ukázaly, že nejvhodnějšími metodami pro toto území jsou Turc a Thornthwaite. Obě zmíněné metody však vykazovaly rozdílný vliv při analýze klimatické změny v období 2021-2060.
\end{abstract}

\section{Klíčová slova}

Klimatická změna, potenciální evapotranspirace, Turc, Thornthwaite

\begin{abstract}
This paper shows usage of four different methods for evaluation of potential evapotranspiration and their effect on the determination of runoff from a river basin under conditions of climate change. Methods are based on mean temperatures and eventually extra-terrestrial radiation. Specifically, the methods are Blaney-Criddle, Hargreaves, Turc and Thornthwaite. Methods were tested using water balance rainfall-runoff hydrological model used on a part of Thaya river catchment. Results shown that the best fitted methods for this study area are Turc and Thornthwaite, however they had a different effect on the analysis of climate change during the period from 2021 to 2060 .
\end{abstract}

Key words

Climate change, potential evapotranspiration, Turc, Thornthwaite

\section{1 ÚVOD}

Šestá hodnotící zpráva Mezivládního panelu pro klimatickou změnu poukazuje na oteplení atmosféry v každém z posledních čtyř desetiletí, které byly teplejší než kterékoli desetiletí před rokem 1850 . K tomuto globálnímu oteplování dochází vlivem postupného zvyšování koncentrací dobře rozmísených (angl. well-mixed) skleníkových plynů v atmosféré, které je jednoznačně způsobeno lidskou činností [1]. Negativní efekt, který tuto klimatickou změnu provází, se projevuje především v koloběhu vody na zemi [2]. Vlivem nárůstu teploty vzduchu dochází k ovlivnění jak srážkových úhrnů, tak i evapotranspirace. Následkem je pak změna hydrologických podmínek v krajině. Především se jedná o změnu odtoku vody jako odezvy povodí na srážku.

Klíčovou součástí koloběhu vody je evapotranspirace. Jedná se o vypařování vody na rozhraní zeměatmosféra a následně její smísení s atmosférou. Vyhodnocení evapotranspirace je velice důležité při studování vlivu klimatické změny na vodní zdroje, jakožto hlavní 'propojení mezi atmosférou a pedosférou v rámci koloběhu vody. Nejpřesnější stanovení evapotranspirace v povodí je pomocí měření tzv. lyzimetry, matematickými modely nebo iterativními metodami [3], [4]. Využití lyzimetrů je však velice náročné z hlediska času i financí [5]. Z těchto důvodů se dává přednost především matematickým modelům definovaným empirickými rovnicemi. Metod pro výpočet evapotranspirace je nespočet a zvolit vhodnou metodu je kritické při modelování srážko-odtokového procesu v povodí. Zmíněné empirické metody však nelze vždy využít pro libovolný časový krok výpočtu modelu nebo pro každé prostředí, protože jejich rovnice jsou založené 
na výsledcích měření $\mathrm{v}$ konkrétních podmínkách. Použití empirických rovnic můžeme označit jako kvalifikovaný odhad a počítáme je v prŕípadech, kdy není možné použít jiné, přesnější metody.

\section{POPIS SOUČASNÉHO STAVU}

V běžných podmínkách lze velmi těžko rozlišit výpar z holé půdy, z povrchu vegetace a transpiraci. Proto se označuje souhrnným pojmem evapotranspirace. Evapotranspirace představuje jednu z nejvýznamnějších ztrátových složek vodní bilance. Její měření nebo jejích složek (transpirace, evaporace, intercepce) se může uskutečňovat $\mathrm{v}$ různých měřítkách, od jednotlivých porostů až po celé povodí [6]. Stanovení výparu se provádí pomocí metod př́mých, nebo metod nepřímých.

Rozlišují se dva druhy evapotranspirace - aktuální a potenciální. Aktuální evapotranspirace představuje množství vody, které je odpařené za jeden běžný den a měří se př́ímými metodami. Měření evapotranspirace přímou metodou znamená, že jsme schopni odečítat úhrn výparu z měřícího př́ístroje, na kterém se voda vypařuje, bez použití dodatečných výpočetních úkonů. Takovými přístroji jsou tzv. lyzimetry, které patří k nejpřesnějším metodám stanovení evapotranspirace [7], [8]. Potenciální evapotranspirace však představuje množství vody, které by mohlo být odpařeno, za předpokladu, že je na sledované oblasti nekonečná nebo také optimální zásoba vody $\mathrm{k}$ odpaření a $\mathrm{k}$ jejímu určení se využívá metod nepřímých. Potenciální evapotranspirace se tedy stanovuje pomocí empirických vzorců [9]. V současnosti je rozpracováno mnoho metod měření a výpočtu evapotranspirace. Vzájemně se liší podle toho, pro jaký vypařující povrch jsou určené a podle časového intervalu, pro který je potřebné určit intenzitu vypařování [10]. Ve většině případů o tom, jaká metoda se použije, rozhoduje kvalita a množství dosažitelných vstupních údajů potřebných pro výpočet.

\section{METODIKA}

Hodnota aktuální evapotranspirace v povodí i velmi často získána právě výpočtem potenciální evapotranspirace, kde se uvažuje s neomezeným množstvím vody dostupným k vypaření a následně je tato hodnota modifikována na základě uvažování aktuálního nasycení půdy v povodí. Modifikace potenciální evapotranspirace se však provádí až při modelování srážko-odtokového procesu v povodí, kdy známe nasycení půdy v povodí pro každý časový krok výpočtu. V prríspěvku jsou porovnány čtyři nejpoužívanější metody stanovení potenciální evapotranspirace, které jsou jednoduché, dostatečně prověřené a potřebné údaje pro výpočet je možné získat standardními měřeními.

\section{Metoda Hargreaves}

Hargreaves a Samani [11] představili hned několik rovnic pro výpočet denní potenciální evapotranspirace. Jedná se o empirickou metodu založenou na průměrné, minimální a maximální denní teplotě vzduchu s využitím průměrného denního extraterestrického záření k upřesnění výpočtu. Stanovení potenciální evapotranspirace touto metodou je matematicky vyjádřeno v následující rovnici:

$$
E_{p 1, i}=0.023 \cdot 0.408 \cdot\left(T_{\text {mean }, i}+17.8\right) \cdot\left(T_{\max , i}-T_{\min , i}\right)^{0.5} \cdot R_{a, i},
$$

kde $E_{\mathrm{p} 1, \mathrm{i}}$ je průměrná denní potenciální evapotranspirace $[\mathrm{mm} / \mathrm{den}], T_{\text {mean,i }}$ je průměrná denní teplota vzduchu $\left[{ }^{\circ} \mathrm{C}\right], T_{\max , i}$ je maximální denní teplota vzduchu $\left[{ }^{\circ} \mathrm{C}\right], T_{\min , \mathrm{i}}$ je minimální denní teplota vzduchu $\left[{ }^{\circ} \mathrm{C}\right]$, $R_{\mathrm{a}, \mathrm{i}}$ je extraterestrické záření $\left[\mathrm{MJ} / \mathrm{m}^{2} / \mathrm{den}\right]$. Určení extraterestrického záření je závislé na poloze povodí, resp. zeměpisné šírce, a pořadí dne v roce. Hodnota je odhadnuta pomocí rovnice (2):

$$
R_{a, i}=\frac{24 \cdot 60}{\pi} \cdot G_{s c} \cdot d_{r, i} \cdot\left[\omega_{s, i} \cdot \sin \left(\varphi_{i}\right) \cdot \sin \left(\delta_{i}\right)+\cos \left(\varphi_{i}\right) \cdot \cos \left(\delta_{i}\right) \cdot \sin \left(\omega_{s, i}\right)\right],
$$

kde $R_{\mathrm{a}, \mathrm{i}}$ je extraterestrické záření $\left[\mathrm{MJ} / \mathrm{m}^{2} / \mathrm{den}\right], G_{\mathrm{sc}}$ je solární konstanta $\left[0.08165 \mathrm{MJ} / \mathrm{m}^{2} / \mathrm{min}\right]$, $\varphi_{\mathrm{i}}$ je průměrná zeměpisná šířka určující polohu povodí [rad], ostatní výpočetní faktory jsou závislé na pořadí dne $\mathrm{v}$ roce a jsou určeny pomocí rovnic (3) až (5).

$$
d_{r, i}=1+0.33 \cdot \cos \left(\frac{2 \pi}{365} \cdot J\right)
$$

kde $d_{\mathrm{r}, \mathrm{i}}$ je inverzní relativní vzdálenost od Země ke Slunci [rad], $J$ je pořadí kalendářního dne v roce [-],

$$
\delta_{i}=0.409 \cdot \sin \left(\frac{2 \pi}{365} \cdot J-1.39\right),
$$

kde $\delta_{\mathrm{i}}$ je solární deklinace [rad], 


$$
\omega_{s, i}=\arccos (-\tan (\varphi) \cdot \tan (\delta)),
$$

kde $\omega_{\mathrm{s}, \mathrm{i}}$ je hodinový úhel západu slunce $[\mathrm{rad}]$.

\section{Metoda Turc}

Je to jedna z nejčastěji používaných rovnic pro výpočet potenciální evapotranspirace hustých porostů, především trávy [12]. Stanovuje denní úhrn potenciální evapotranspirace pro dny s kladnými průměrnými teplotami vzduchu. Forma výpočtu je velice podobná metodě Hargreaves. K výpočtu vyžaduje informaci o průměrné denní teplotě vzduchu, průměrnou denní hodnotu solárního záření a délku slunečního svitu pro jednotlivé dny v roce. Vzorec pro výpočet průměrné denní potenciální evapotranspirace je vyjádřen v rovnici (6).

$$
E_{p 2, i}=10 \cdot 0.0133 \cdot\left(\frac{T_{\text {mean }, i}}{T_{\text {mean }, i}+15}\right) \cdot\left(R_{s, i}+50\right),
$$

kde $E_{\mathrm{p} 2, \mathrm{i}}$ je průměrná denní potenciální evapotranspirace $[\mathrm{mm} / \mathrm{den}], 10$ je koeficient převodu jednotek z $\mathrm{cm}$ na mm, $T_{\text {mean,i }}$ je průměrná denní teplota vzduchu $\left[{ }^{\circ} \mathrm{C}\right]$ a $R_{\mathrm{s}, \mathrm{i}}$ je solární záření odhadnuté pomocí rovnice $(7)$ vycházející z extraterestrického záření vypočítané rovnicí (2).

$$
R_{s, i}=0.16 \cdot\left(T_{\max , i}-T_{\min , i}\right)^{0.5} \cdot R_{a, i}
$$

kde $R_{\mathrm{s}, \mathrm{i}}$ je denní solární záření $\left[\mathrm{MJ} / \mathrm{m}^{2} / \mathrm{den}\right], T_{\max , \mathrm{i}}$ je maximální denní teplota $\left[{ }^{\circ} \mathrm{C}\right], T_{\min , \mathrm{i}}$ je minimální denní teplota $\left[{ }^{\circ} \mathrm{C}\right]$ a $R_{\mathrm{a}, \mathrm{i}}$ je extraterestrické záření $\left[\mathrm{MJ} / \mathrm{m}^{2} / \mathrm{den}\right]$.

\section{Metoda Thornthwaite}

Jedná se nejvíce využívanou z uvedených metod. Byla vytvořena pro klimatické podmínky ve střední oblasti Spojených států amerických [13]. Vyžívá se však celosvětově. Odhaduje potenciální evapotranspiraci pro standardní měsíc o 30 dnech, kde každý den má 12 hodin slunečního svitu, jako funkci průměrné měsíční teploty vzduchu. Výpočet se provádí pouze pro kladné hodnoty průměrné teploty vzduchu.

$$
E_{p 3, i}=16 \cdot\left(10 \cdot \frac{T_{m e a n, i}}{I_{u}}\right)^{a_{u}} \cdot C
$$

kde $E_{\mathrm{p} 3, \mathrm{i}}$ je průměrná denní potenciální evapotranspirace $[\mathrm{mm} / \mathrm{den}], T_{\text {mean,i }}$ je průměrná denní teplota vzduchu $\left[{ }^{\circ} \mathrm{C}\right], I_{\mathrm{u}}$ je teplotní index $u$-tého roku pro $u=1,2, \ldots, v$, kde $v$ je počet let časové řady měřených dat, $a_{\mathrm{u}}$ je empirický koeficient představující funkci teplotního indexu [-], $C$ je parametr pro přepočet metody na denní krok výpočtu, který je dán vztahem (9):

$$
C=\frac{N_{i}}{360},
$$

kde $N_{\mathrm{i}}$, je délka slunečního svitu v $i$-tém dni a je jeho stanovení je vyjádřeno rovnicí (10):

$$
N_{i}=\frac{24}{\pi} \cdot \omega_{s, i}
$$

kde $\omega_{\mathrm{s}, \mathrm{i}}$ je hodinový úhel západu slunce [rad] (rovnice (5)).

\section{Metoda Blaney-Criddle}

Metoda je velice přímočará, protože pro výpočet potenciální evapotranspirace uvažuje pouze průměrnou denní teplotu a délku denního slunečního svitu [14]. Pro denní krok výpočtu je odhad proveden následujícím vztahem:

$$
E_{p 4, i}=p_{i} \cdot\left(0.46 \cdot T_{\text {mean }, i}+8\right),
$$

kde $E_{\mathrm{p} 4, \mathrm{i}}$ je průměrná denní potenciální evapotranspirace $[\mathrm{mm} / \mathrm{den}], T_{\text {mean,i }}$ je průměrná denní teplota vzduchu $\left[{ }^{\circ} \mathrm{C}\right], p_{\mathrm{i}}$ je průměrné denní procento z celkové délky ročního slunečního svitu [\%], které je závislé na průměrné poloze povodí, resp. zeměpisné šířce. Př́stupy k získání tohoto procenta jsou dva. První uvažuje toto procento konstantní pro celý měsíc a jeho hodnoty vycházejí z již přepočítaných tabulek pro jednotlivé zeměpisné šířky. Druhý uvažuje se změnou délky svitu pro každý den v roce. V tomto př́íspěvku je využito druhého přístupu a hodnoty $p_{\mathrm{i}}$ jsou stanoveny pro každý krok výpočtu (den) pomocí rovnice (12):

$$
p_{i}=\frac{N_{i}}{4380} \cdot 100 \text {, }
$$


kde $N_{\mathrm{i}}$ je denní délka slunečního svitu [hod], 4380 je celkový počet hodin denního slunečního svitu v roce. Rovnice (1) až (12) jsou pro $i=1,2, \ldots, n$, kde $n$ je délka časové řady měřených dat.

\section{VÝSLEDKY}

Vybrané metody výpočtu potenciální evapotranspirace byly testovány na části povodí řeky Dyje o ploše $2124.2 \mathrm{~km}^{2}$, reprezentující sběrnou plochu přítoku do vodní nádrže Vranov. Na tomto zájmovém území byla použita data průměrných, maximální a minimální denních teplot vzduchu zprůměrovaných ze 3 meteorologických stanic, data denních úhrnů srážek zprůměrovaných z 12 srážkoměrných stanic a pro kalibraci modelu data velikosti odtoků z povodí ze dvou hydrometrických profilů. Data byla poskytnuta pro období let od 1991 do 2014.

Pro porovnání metod byl zvolen bilanční srážko-odtokový hydrologický model, který simuluje srážkoodtokový proces na zvoleném povodí jako celku. Délka kalibračního období byla volena od 1991 do 2007. Během kalibrace modelu je vypočtená potenciální evapotranspirace modifikována parametrem modelu a podílem nasycení půdy $\mathrm{v}$ aktuálním časovém kroku výpočtu a maximálním nasycením půdy v povodí. Model byl kalibrován s využitím kalibračního kritéria Nash-Sutcliffe (NSE) [15]. Výsledné hodnoty kalibračního kritéria pro jednotlivé metody je uvedeno v Tab. 1.

Tab. 1 Výsledné kalibrační kritérium pro zvolené metody výpočtu potenciální evapotranspirace.

\begin{tabular}{cc}
\hline Metody výpočtu potenciální evapotranspirace & Hodnoty kritéria NSE při kalibraci modelu \\
\hline Hargreaves & 0.515 \\
Turc & 0.606 \\
Thornthwaite & 0.565 \\
Blaney-Criddle & 0.539 \\
\hline
\end{tabular}

Dle [16] je model s kalibračním kritériem NSE vyšším než 0.50 považován za uspokojivý. Z Tab. 1 je patrné, že při použití jakékoliv metody vykazuje model uspokojivých výsledků. Průměrné roční potenciální evapotranspirace získané jednotlivými metodami na kalibrovaném období jsou uvedeny v následující tabulce.

Tab. 2 Průměrné roční potenciální evapotranspirace získané jednotlivými metodami pro kalibrační období 1991 až 2007.

\begin{tabular}{cc}
\hline Metody výpočtu potenciální evapotranspirace & Průměrní roční potenciální evapotranspirace \\
\hline Hargreaves & 599.7 \\
Turc & 770.5 \\
Thornthwaite & 593.4 \\
Blaney-Criddle & 1237.8 \\
\hline
\end{tabular}

Dle Atlasu podnebí Česka je průměrná roční referenční evapotranspirace pro zájmové území přibližně $700 \mathrm{~mm}$ [17]. Z Tab.2 lze pozorovat, že této hodnotě se nejvíce přiblížily metody Turc a Hargreaves. Metoda Hargreaves dosahuje hodnoty nižší, naopak metoda Turc hodnoty vyšší vůči referenční hodnotě.

Model kalibrovaný na každou metodu byl následně využit pro výpočet odtoků z povodí při uvažování klimatické změny v období mezi roky 2021 a 2060. Pro modelování klimatické změny byl využit ensemble devíti klimatických scénářů vygenerovaných v softwaru LARS WG [18]. Porovnání vlivu jednotlivých metod výpočtů potenciální evapotranspirace na odtokový režim bylo provedeno pomocí dlouhodobých průměrných průtoků.

Tab. 3 Dlouhodobé průměrné průtoky pro jednotlivé klimatické scénáře pro období let 2021 až 2060 s využitím různých metod výpočtu potenciální evapotranspirace (hodnoty jsou uvedeny $\mathrm{v} \mathrm{m}^{3} / \mathrm{s}$ ).

\begin{tabular}{cccccccccc}
\hline \multirow{2}{*}{ Metody } & Scénář & Scénář & Scénář & Scénář & Scénář & Scénář & Scénář & Scénář & Scénářr \\
& $\mathbf{1}$ & $\mathbf{2}$ & $\mathbf{3}$ & $\mathbf{4}$ & $\mathbf{5}$ & $\mathbf{6}$ & $\mathbf{7}$ & $\mathbf{8}$ & $\mathbf{9}$ \\
\hline Hargreaves & 6.926 & 6.938 & 5.959 & 6.048 & 6.173 & 6.795 & 6.599 & 6.279 & 6.715 \\
Turc & 6.811 & 6.590 & 5.614 & 5.587 & 5.531 & 6.722 & 6.068 & 6.286 & 6.667 \\
Thornthwaite & 9.001 & 8.790 & 7.793 & 7.730 & 7.697 & 9.092 & 8.404 & 8.416 & 8.933 \\
Blaney-Criddle & 9.184 & 9.165 & 8.036 & 8.074 & 8.270 & 9.225 & 8.966 & 8.392 & 8.885 \\
\hline
\end{tabular}

Tab. 3 ukazuje velice různorodé hodnoty dlouhodobých průměrných průtoků pro jednotlivé scénáře při využití jednotlivých metod výpočtu potenciální evapotranspirace. Variační rozpětí dlouhodobých průměrných průtoků 
pro jednotlivé scénáře se pohybuje mezi $2.137 \mathrm{~m}^{3} / \mathrm{s}$ a $2.898 \mathrm{~m}^{3} / \mathrm{s}$. Pokud budeme uvažovat minimální hodnoty jako základ, jedná se o rozdíl hodnot $34 \%$ až $49 \%$.

\section{DISKUZE}

Z výsledků je patrné, že volba metody stanovení potenciální evapotranspirace hraje při modelování srážkoodtokového procesu velkou roli. Pro všechny vybrané metody se podařilo srážko-odtokový model zkalibrovat na hodnoty kritérií představující uspokojivé simulované výsledky. Přesto se výsledky vzájemně velmi liší. Proto je důležité dokázat rozlišit, která metoda je nejvhodnější pro zvolené území. Toho se docílí bud’to kalibrací metod, která je však náročná na získání potřebných měřených dat, anebo porovnáním průměrný hodnot $\mathrm{s}$ hodnotami $\mathrm{z}$ tabulek. $\mathrm{V}$ tomto př́ípadě byl použit Atlas podnebí Česka, kdy se porovnáním průměrné roční referenční evapotranspirace a průměrné roční potenciální evapotranspirace ukázala jako nejvhodnější metoda Turc.

\section{ZÁVĚR}

Problematika modelování srážko-odtokového procesu v povodí v podmínkách klimatické změny je velice komplexní a analýza hydrologických data zatížených klimatickou změnou s sebou nese spoustu nejistot. Dle šesté hodnotící zprávy Mezivládního panelu pro klimatickou změnu je jednoznačné, že sledované negativní vlivy na globální klimatický systém, jejichž důsledkem je změna klimatu, je způsobena lidskou činností. Je velmi pravděpodobné, že rostoucí trend globální teploty bude pokračovat v blízké budoucnosti, a proto je vyhodnocení predikovaných dat klíčové. Budoucí vývoj klimatu je velice nejistý. Je tedy nutné omezit vstup dalších nejistot vycházejících z matematických modelů na minimum a jak je z výsledků patrné, volba nevhodné metody pro výpočet jedné složky srážko-odtokového procesu v povodí může výsledná data zkreslit. Následkem takovéto volby může být např́klad předimenzování nebo poddimenzování navrženého opatření pro adaptaci na klimatickou změnu.

\section{Poděkování}

Tento př́spěvek je výsledkem specifického výzkumu FAST-J-21-7371 „Nástroje pro zvládání klimatické změny a zajištění udržitelného rozvoje ve vodním hospodářství krajiny“.

\section{Použité zdroje}

[1] IPCC. Climate Change 2021: The Physical Science Basis. Contribution of Working Group I to the Sixth Assessment Report of the Intergovernmental Panel on Climate Change. Cambridge University Press. 2021.

[2] SKILES, J. W. a Jon D. HANSON. Responses of arid and semiarid watersheds to increasing carbon dioxide and climate change as shown by simulation studies. Climatic Change [online]. 1994, 26(4), 377-397. ISSN 0165-0009. Dostupné z: doi:10.1007/BF01094403

[3] ALLEN, R. G., PEREIRA, L. S., RAE, D., SMITH, M. Crop evapotranspiration. Guidelines for computing crop water requirements. FAO Irrigation and Drainage. Paper no. 56. FAO, Rom. 1994

[4] WIDMOSER, P. A discussion on and alternative to the Penman-Monteith equation. Agricultural Water Management [online]. 2009, 96(4), 711-721. ISSN 03783774. Dostupné z: doi:10.1016/j.agwat.2008.10.003

[5] IRMAK, S., A. IRMAK, R. G. ALLEN a J. W. JONES. Solar and Net Radiation-Based Equations to Estimate Reference Evapotranspiration in Humid Climates. Journal of Irrigation and Drainage Engineering [online]. 2003, 129(5), 336-347. ISSN 0733-9437. Dostupné z: doi:10.1061/(ASCE)0733-9437(2003)129:5(336)

[6] RANA, G. a N. KATERJI. Measurement and estimation of actual evapotranspiration in the field under Mediterranean climate: a review. European Journal of Agronomy [online]. 2000, 13(2-3), 125153.ISSN 11610301. Dostupné z: doi:10.1016/S1161-0301(00)00070-8

[7] AHMADPARI, H., HASHEMI GARMDAREH, S., GHALHKOHNEH, K. Comparison of different methods of estimating potential evapotranspiration by FAO Penman Monteith (Case Study: Sepidan Region). Nivar, 41(98-99), 13-22, 2017.

[8] MOŽNÝ, M. Evaporace a evapotranspirace: sborník z mezinárodního vědeckého semináře .. [online]. [Praha]: Český hydrometeorologický ústav, 2005-^^^^. ISBN 80-866-9024-5. ISSN Problematika 
měření evapotranspirace v ČHMŮ. Dostupné z: http://www.cbks.cz/sbornik05/prispevky/mozny1.pdf

[9] KARLSSON, E. a L. POMADE. Methods of estimating potential and actual evaporation, Department of Water Resources Engineering.

[10] YATES, D. a K. STRZEPEK. Potentialevapotranspiration methods and their impact on the assessment of river basin runoff under climate change. International Institute of Applied Systems Analysis Working Papers, 1994, 94-46. 28.

[11] HARGREAVES, G. a Z. SAMANI. Reference Crop Evapotranspiration from Temperature. Applied Engineering in Agriculture [online]. 1985, 1(2), 96-99. ISSN 1943-7838. Dostupné z: doi: $10.13031 / 2013.26773$

[12] TURC, L. Water requirements assessment of irriga- tion, potential evapotranspiration: Simplified and updated climatic formula. Annales Agronomiques. 1961, 12, 13-49.

[13] THORNTHWAITE, C. W. An Approach toward a Rational Classification of Climate. Geographical Review [online]. 1948, 38(1). ISSN 00167428. Dostupné z: doi:10.2307/210739

[14] NASH, J.E. a J.V. SUTCLIFFE. River flow forecasting through conceptual models part I - A discussion of principles. Journal of Hydrology [online]. 1970, 10(3), 282-290. ISSN 00221694. Dostupné z: doi:10.1016/0022-1694(70)90255-6

[15] MORIASI, D. N. Hydrologic and Water Quality Models: Performance Measures and Evaluation Criteria. Transactions of the ASABE [online]. 2015, 58(6), 1763-1785. ISSN 21510032. Dostupné z: doi: $10.13031 / \operatorname{trans} .58 .10715$

[16] TOLASZ, R. Atlas podnebí Česka: Climate atlas of Czechia. Praha: Český hydrometeorologický ústav, 2007. ISBN 978-80-86690-26-1.

[17] RACSKO, P., SZEIDL, L. a M. SEMENOV. A serial approach to local stochastic weather models. Ecological Modelling, 1991, 57(1-2), 27-41. https://doi.org/10.1016/0304-3800(91)90053-4 